位置情報から算出した加速度がサッカーを想定した短時間の間欠的運動中の エネルギー消費量に対する貢献

\author{
東野 祐哉 ${ }^{1}$, 綾部 誠也 ${ }^{2}$, 沖田 剛輝 $^{1}$, 土方 泰知 $^{2}$, 森村 和浩 $^{3}$, 石㟝 聡之 $^{4}$
}

\title{
Contribution of acceleration by location tracking system to energy expenditure during Soccer -based intermittent exercise
}

\author{
Yuya Higashino ${ }^{1}$, Makoto Ayabe ${ }^{2}$, Yoshiki Okita ${ }^{1}$, Taichi Hijikata ${ }^{2}$, \\ Kazuhiro Morimura ${ }^{3}$ and Satoshi Ishizaki ${ }^{4}$
}

${ }^{1}$ 岡山県立大学大学院情報系工学研究科，干719-1197 岡山県総社市窪木111 (Graduate School of Computer Science and Systems Engineering, Okayama Prefectural University, 111 Kuboki, Soja, Okayama 719-1197, Japan)

${ }^{2}$ 岡山県立大学情報工学部, ⿳7一79-1197 岡山県総社市窪木111 (Faculty of Computer Science and Systems Engineering, Okayama Prefectural University, 111 Kuboki, Soja, Okayama 719-1197, Japan)

就実大学教育学部， ₹703-8516 岡山県岡山市中区西川原1-6-1 (Faculty of Education, Shujitsu University, 1-6-1 Nishigawara, Naka-ku, Okayama-shi, Okayama 703-8516, Japan)

4 芝浦工業大学工学部, ７337-8570 埼玉県さいたま市見沼区深作 307 (Faculty of Engineering, Shibaura Institute of Technology, 307 Fukasaku, Minuma-ku, Saitama-shi, Saitama 337-8570, Japan)

Received: March 20, 2018 / Accepted: July 19, 2018

\begin{abstract}
The purpose of this study was to examine the contribution of the location-tracking information to the energy expenditure during the soccer-based intermittent sprint run. Twentyfour young healthy men participated in the present investigation (1st experiment: $14 \mathrm{men}, 2 \mathrm{nd}$ experiment $10 \mathrm{men}$ ). In the 1 st experiment, the sprint runs were 12 times of the $10 \mathrm{~m}$ (SS10), or 6 times of the $20 \mathrm{~m}$ (SS20), or td 3 times of the $40 \mathrm{~m}$ (SS40). In the 2nd experiment, the sprint runs 15 times of the $10 \mathrm{~m}$ (SS), or 15 times of the $10 \mathrm{~m}$ of the sprint run with change of direction for 90, 135, 180 degrees (CD90, CD135 and CD180). All course of the experiment, the expired gas was analyzed using the portable gas analyzer. The running index including speed, acceleration, distance, were calculated at $15 \mathrm{~Hz}$ interval based on the location-tracking information using the portable global positioning system. The intermittent run with the straight sprint run expended significantly larger calorie compared with that without the straight sprint $(\mathrm{p}<0.001)$. The intermittent run with the changes of direction expended significantly larger calorie compared with that without the changes of direction $(\mathrm{p}<0.05)$. A multiple stepwise regression analysis revealed that body weight, the acceleration and the change of direction were significant determinants of the energy expenditure and accounted for $75 \%$ of the total variance. These results indicate that the magnitude of the acceleration is significant predictor for the energy expenditure of the intermittent exercise.
\end{abstract}

Jpn J Phys Fitness Sports Med, 67(6): 411-421 (2018)

Keywords : tracking, football, metabolic power, metabolic cost, cardiorespiratory

\section{緒言}

サッカーは，世界で人気のあるスポーツのひとつであ る。サッカーは，競技人口が全世界で 2 億 6500 万人に至 $\eta^{1)} ， 4$ 年に一度の世界大会には五輪と同等の 207 ヶ国 が参加する ${ }^{1)}$ 。また，サッカーは，トップレベルの競技 選手のみならず, 若年者や女性での世界大会が開催され, 子どもから大人まで幅広い年齢が参加する競技スポーツ である。さらには，近年，サッカーがレクリエーション
として中高齢者への健康づくりのための運動に応用され ている. Krustrup ら ${ }^{2,3)}$ は, サッカーの継続的実施が身 体機能の向上, 疾病の予防に効果的である可能性を示唆 している。このように, サッカーは, プロスポーツから 健康づくりの目的まで様々な場面での活躍が期待されて おり，競技力向上や疾病予防のための身体の応答・適応 についての研究が続けられている ${ }^{4-6)}$.

サッカーの競技特性の一つは，ボールを蹴るというこ とであるが，選手一人当たりがボールに直接的にプレー 
している時間が 1 分程度であり, 歩行や走行などの走運 動が大半を占めている ${ }^{7)}$. 試合中の移動形態は, 試合全 体での総移動距離が 10,000 から $11,000 \mathrm{~m}$ であり ${ }^{8-10)}$, そ のうち, 高強度のスプリント走行が占める距離が 200$300 \mathrm{~m}$, ジョギングの占める距離が4,000-5,000 m であり, 全体の $50 \%$ 程度の距離がジョギングにも至らない強度 での活動である ${ }^{10)}$. 従って, サッカーは, 試合中の 1 分 間あたりの移動距離が 100-150 m 程度であり, ジョギン グに相当する速度で移動していることになる ${ }^{11)}$ ，ただし， サッカー試合中の心拍数 (heart rate: HR) は171から 205 拍/分まで上昇し ${ }^{12)}$ ，大部分の時間で $80 \% H R m a x に$ 相当することが 20 歳から 75 歳の非鍛錬者, マスターア スリート, 糖尿病患者, がん患者を対象とした研究成果 で報告されている ${ }^{13)}$ 。また, 間欠的運動時の呼吸循環応 答が平均運動強度に必ずしも対応しないことが知られて 㧍り, 間欠的運動中の HR, 酸素摂取量 (oxygen uptake: $\dot{\mathrm{V}} \mathrm{O}_{2}$ ), 換気量 (ventilation: $\dot{\mathrm{V} E}$ ) が同一運動量の固定 負荷運動に比して高くなる ${ }^{14)}$ 。それ故, サッカーは, 80\%HRmax 超える高強度運動パフォーマンスをジョ ギング活動時に回復しながら 90 分間に渡って繰り返す 走運動能力が求められる ${ }^{15}$

これまで, サッカーの実際の試合中の移動形態の特徵 や分析方法に関する情報は少なかったが，近年の科学技 術の革新により著しく発展した映像分析や衛星位置情報 システム（Global Positioning System）を利用すること により実際の試合中の移動形態が高精度で分析可能に なった ${ }^{8-10,16)}$ 。すなわち, 従来の三角測量法 ${ }^{17)}$ やカメラ での位置座標を用いた手法 ${ }^{18)}$ は, 測定対象者数が限られ ていたり, 分析に莫大な手間と時間が必要であったため, 実際の試合のデータとしては限定的であった。しかし， 映像分析に打ける自動追尾技術の進展やGPS機器の小 型化により，複数選手を対象に試合全体を通じた連続的 な移動形態を客観的に評価できるようになり，国際サッ カー連盟や世界のプロサッカーリーグが主催する公式試 合でも利用が国際的に承認されるまでに至った。日本の プロサッカーリーグ（ J リーグ）も2015年シーズンから 公式戦での位置情報分析を利用して㧍り，ホームページ などで出場選手毎の試合中の総移動距離と $24 \mathrm{~km} / \mathrm{h}$ 以上 の速度で 1 秒以上走行した回数を発表している。 その結 果, 興味深いことに, 2015から 2017 シーズンの 3 シーズ ンにおけるJリーグの優勝チームの総移動距離合計の順 位は，18チーム中 14 位から 17 位であった，また，同 3 チームの $24 \mathrm{~km} / \mathrm{h}$ 以上の速度で 1 秒以上走行した回数 は，18チーム中 2 位から 17 位であった ${ }^{19)}$ 。これらの結 果は, 総移動距離とスプリント走回数がチーム順位に必 ずしも関係しないことを示唆している。このようにサッ カーの実際の試合中の移動形態の分析は, 近年の技術革 新に伴って客観的評価の環境が整備されており, 新たな
評価指標の開発や身体負担や臨床データとの関連を含め た新たな位置情報の分析方法が期待されている.

映像分析や GPSでは，20-30 Hzでのサンプリング頻 度でのデー夕収集が可能であるため, 移動距離や一定速 度以上での走行回数などの量的評価に留まらず，瞬間的 な移動形態を評価できる. Osgnach ら ${ }^{9)}$ は, 映像分析に よりサッカー試合中における加速度の大きさ毎の時間を 分析し, $-3 \mathrm{~m} \cdot \mathrm{s}^{-2}$ 以下が50秒, -3 から $-2 \mathrm{~m} \cdot \mathrm{s}^{-2}$ が 128 秒, -2から $-1 \mathrm{~m} \cdot \mathrm{s}^{-2}$ が448秒, また, 2 から $3 \mathrm{~m} \cdot \mathrm{s}^{-2}$ が133秒, $3 \mathrm{~m} \cdot \mathrm{s}^{-2}$ 以上が51秒であったことを報告した。 さらに, Bloomfieid ${ }^{20)}$ は, 映像分析を用いて角度ごとでの方 向転換の回数を評価し，0-90の方向転換が609回，90$180^{\circ}$ の方向転換が 94.5 回, 180-270の方向転換が5.6回, 270-360の方向転換が 1.7 回であったと報告した。この ように, サッカーの試合中の移動形態の判別は, 近年の 技術革新によって，1 試合あたりの移動距離のみならず, 位置情報の詳細な変動に基づいた瞬時の加速度の分析も 可能になり，今後の技術革新やルール改正による普及も 期待される.

さらに，このような位置情報を選手の身体疲労の評価 などに応用することができれば，選手の競技力向上の支 援に有用な情報になる。エネルギー消費量（energy expenditure: EE）は，競技中の選手の身体負担を定量でき る指標であり, パフォーマンスの向上や競技の安全性を 確保する上で幅広く利用されている。これまでの研究に おいては, 二重標識水法により日本人のプロサッカー選 手の 1 日の総 $\mathrm{EE}$ が $3,532 \mathrm{kcal} / \mathrm{day}$ であったこと ${ }^{21)}$ ，ま た，実験環境下で得られた $\dot{\mathrm{V}} \mathrm{O}_{2}$ と $\mathrm{HR}$ の関係式に基づい てサッカーの競技中の HRから推定した EEが練習中や フットサルを含めて500-600 kcalであることが報告され てきた ${ }^{22-24)}$. これらの方法の応用に際しては，動作に対 する $\mathrm{EE} の$ 個人差が少ないこと, また, 競技中の動作特 性が一律であることが前提とされるが, 残念ながら, サッ カーの実際の試合中の選手個々の動作は対戦相手や試合 展開に依存する。一方, 位置情報に基づいて EE を推定 することができれば，動作を実測するため，サッカー特 有の不規則性に原因する $\mathrm{EE}$ 推定の限界点を軽減するこ とができる。 Osgnach $ら^{9)}$ は, 試合中の選手の映像分析 から取得された移動形態から, di Prampero ${ }^{25)}$ が提案 した加速度と減速度による EEの推定法を用いた 1 試合 の $\mathrm{EE}$ が1106 kcal程度であることを報告した。ただし， di Pramperoら ${ }^{25)}$ の方法については, 位置情報から得ら れる加速度・減速度を用いた $\mathrm{EE}$, また, 移動速度を加 味して算出するメタボリックパワーについては，ドリブ ル動作時や方向転換走の条件下での呼気ガス分析法との 比較に打いて，その測定誤差が指摘されている。これら の知見は，位置情報が多人数を対象にサッカーの試合展 開などを踏まえた身体負担の評価をリアルタイムに評価 
することができる可能性があるものの，位置情報に基づ く $\mathrm{EE}$ 推定アルゴリズムについての検討が必要であるこ とを示している，すなわち, 走行中の加速度・減速度と $\mathrm{EE}$ 関係についてはさらなる検討が必要であり, 平均 速度やメタボリックパワーを含めた位置情報から得られ る移動形態の指標が $\mathrm{EE}$ に対する貢献度を検討する必要 がある。

本研究は, サッカー競技中の EEを明らかにするため の基礎的研究として, スプリント走距離や方向転換角度 が異なる条件下の間久的運動時の EEに対する加速度の 貢献を明らかにすることを目的とした。すなわち，本研 究は, サッカーを想定した短距離スプリント走を含む間 欠的運動において, 加速度が EE の説明要因であるとの 仮説を検証するために, 走行中の加速度の差を得るため の条件として, 総距離が同一で単回あたりの距離が異な るスプリント走の間欠的運動条件（実験 1 ), 方向転換 角度が異なるスプリント走の間欠的運動条件（実験 2) での実験を実施した。

\section{方 法}

対象者 本研究の対象者は習慣的に運動を行なっている サッカー経験のある男子大学生（実験 1：18から 23歳 の14名, 実験 2：18から22歳の10名）であった，全ての 対象者には, 事前に本研究の目的や実験方法, 実験に伴 う危険性などについて説明した上で，書面による同意を 得た。本研究は, 全てのプロトコールをヘルシンキ宣言 に従って行い, 研究実施前に岡山県立大学倫理委員会の 承認を得た（承認番号：16-65）。

実験に先立ち，全対象者の身長，体重，身体組成を測 定した。身長は，デジタル身長計（ムラテック KDS 株 式会社, 京都, 日本) にて測定した。体重と身体組成は MC-780A（株式会社タニタ, 東京, 日本）にて測定した。 年齢, 身長, 体重, 除脂肪量, 体脂肪率, サッカー経験 年数は, Table 1に示した.

実験プロトコール 実験 $1 ：$ 全ての対象者は，4 条件で の $1,200 \mathrm{~m}$ の間欠的運動を用いた運動負荷試験を実施し
た．全ての実験は，屋外の陸上競技用 $400 \mathrm{~m}$ トラックに てランニングシューズを履いて行なった. 実験に際して, 全ての対象者は，実験前日の激しい運動を禁止され，実 験開始前 3 時間から水を除く飲食を禁止された。

測定は，5分間の座位安静の後，4条件での主運動を それぞれ 10 分 30 秒間実施した。各試行間には 10 分間の 座位安静を設けた。間欠的運動のプロトコールは, 実際 のサッカー場面に近づけるため, これまでのサッカーに 関する先行研究に基づいて設計された。 4 つの条件は, スプリント走なし (no straight sprint: NSS), $10 \mathrm{~m} \times$ 12 (SS10), $20 \mathrm{~m} \times 6$ (SS20), $40 \mathrm{~m} \times 3$ (SS40) であっ た。これは，サッカーの戦術的観点でグラウンドの 3 分 割 (30-40 m) と同程度の距離であること ${ }^{26,27)}$ ，また，実 際の試合でのスプリント走時の距離は 200-300 m 程度 ${ }^{10)}$ で，30-40回8) 行われていることからサッカー試合中の 一回のスプリント走距離が 10-40 m であることを想定し 距離を決定した。スプリント走回数は，実際の試合での スプリント走回数から 1 分あたりのスプリント走回数を 算出し, それを本研究の 1 試行あたりの運動時間に換算 すると3-4回となるため，スプリント走条件で最も距離 の長い $40 \mathrm{~m}$ を基準に $1,200 \mathrm{~m}$ あたり $120 \mathrm{~m}$ のスプリント 走を各スプリント走条件で行えるように，それぞれのス プリント走回数を $10 \mathrm{~m} \times 12,20 \mathrm{~m} \times 6,40 \mathrm{~m} \times 3$ に決定 した４条件での所要時間は, サッカー選手の一試合 の総移動距離が10,000-11,000 $\mathrm{m}^{8-10)}$ であることに基づい て，その距離を $1,200 \mathrm{~m}$ に換算して 10 分 30 秒に統一した. 全ての条件において，スプリント走開始時に一旦停止し てから急加速を行い，スプリント走終了地点で急減速し 完全に停止するように指示した，スプリント走を含む 3 条件の試行順序は無作為に決定した。な押，各条件開始 直前の $\mathrm{HR}, \dot{\mathrm{V}} \mathrm{O}_{2}, \dot{\mathrm{V}} \mathrm{CO}_{2}, \dot{\mathrm{V}} \mathrm{E}$ は, 条件間で有意な差がな いことを実験後の分析により確認した。

実験 2：全ての対象者は，4条件での $1,200 \mathrm{~m}$ の間欠的 運動を用いた運動負荷試験を実施した。全ての実験は, 屋外の陸上競技用 $400 \mathrm{~m}$ トラックおよび天然芝のサッ カー競技場にてサッカースパイクを履いて行なった.

Table 1. Characteristics subjects.

\begin{tabular}{lcc}
\hline & Experiment 1 $(\mathrm{n}=14)$ & Experiment 2 $(\mathrm{n}=10)$ \\
\hline Age (years) & $21 \pm 1$ & $21 \pm 2$ \\
Height $(\mathrm{cm})$ & $173.3 \pm 6.6$ & $170.9 \pm 4.6$ \\
Body weight (kg) & $65.6 \pm 9.6$ & $63.2 \pm 9.5$ \\
Lean body mass (kg) & $56.1 \pm 6.1$ & $53.3 \pm 5.5$ \\
Percent fat (\%) & $13.9 \pm 5.0$ & $15.0 \pm 5.2$ \\
Soccer history (years) & $14 \pm 3$ & $14 \pm 2$ \\
\hline
\end{tabular}

Date are shown as mean with standard deviation 
測定は，5分間の座位安静の後，4 条件での主運動を それぞれ 10 分 30 秒実施した。各試行間には 10 分間の座 位安静を設けた. 間欠的運動負荷試験のプロトコールは, 実験 1 と同様に実際のサッカー場面に近づけるため, こ れまでのサッカーに関する先行研究に基づいて設計され た４つの条件は，直進スプリント走 (straight sprint； SS), $90^{\circ}$ の方向転換を含むスプリント走 (change of direction；CD90), $135^{\circ}$ の方向転換を含むスプリント走 (CD135)，180の方向転換を含むスプリント走 $(\mathrm{CD} 180)$ であった１回あたりのスプリント走の距離と回数は, $10 \mathrm{~m}$ とした. 実験 2 は, 実験 1 で得られたスプリント走 距離の分割にて $10 \mathrm{~m}$ スプリント走時に $\mathrm{EE}$ が増大するこ とに基づき， $10 \mathrm{~m}$ スプリント走の中に方向転換を含む

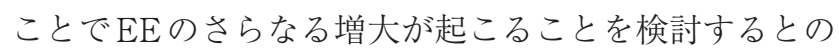
観点からスプリント走距離 $10 \mathrm{~m}$ と設定した。また， 1 回あたりの方向転換の角度と回数は $90^{\circ}, 135^{\circ}, 180^{\circ}$ で それぞれ15回とした。これは，実際のサッカー試合中の 方向転換は，1試合で合計約 727 回行われており，その 中でも0-180の方向転換が約 97\%行われていることに 基づいて方向転換の角度は, $90^{\circ}, 135^{\circ}, 180^{\circ}$ とした ${ }^{20)}$. 4 条件での $1,200 \mathrm{~m}$ 走の所要時間は, 実験 1 と同様, 10 分30秒に統一した，全ての条件に拀いて，スプリント走 開始時に一旦停止してから急加速を行い, $5 \mathrm{~m}$ の地点で ターンを行い，スプリント走終了地点で急減速し完全に 停止するように指示した，方向転換を伴うスプリント走 の 3 条件の試行順序は無作為に決定した。 なお，各条件 開始直前の $\mathrm{HR}, \dot{\mathrm{V}} \mathrm{O}_{2}, \dot{\mathrm{V} C O} 2, \dot{\mathrm{V}} \mathrm{E}$ は, 条件間で有意な差 がないことを実験後の分析により確認した。
測定項目 移動距離，走行速度，加速度，HRはSPI Pro X (GPSPORTS, キャンベラ, オーストラリア) にて測定 した. SPI Pro Xは，位置情報をサンプリング頻度 $15 \mathrm{~Hz}$ にて計測するシステムであり, 先行研究によって実測值 との比較により 0-3\%程度の誤差範囲で距離を評価可能 なことが明らかにされている ${ }^{28)}$ ，対象者は，実験開始か ら終了までSPI Pro Xを専用のべストの背中部分に装着 した，移動距離は，15 Hzで得られる位置情報の変化量 の積算值として $1 / 15$ 秒毎に評価した。走速度は, 移動距 離を時間で除して $1 / 15$ 秒毎に評価した。加速度は, 走 速度の変化量を $1 / 15$ 秒毎に算出した. HRは，HR測定胸 部ストラップH10（Polar Electro, ケンペレ, フィンラン ド）からの信号をSPI Pro XにてBluetoothにて接続し, 1/15秒毎に評価した．SPI Pro Xによって得られたデー 夕は, 実験終了後にコンピュータに転送し, 専用分析ソ フトTEAM AMS (GPSPORTS, キャンベラ, オーストラ リア）にて分析した．スプリント走区間とジョギング区 間の移動形態は，位置情報から得られる走行地点から区 分した。平均速度は，スプリント走区間とジョギング区 間の両者を含む試行条件全体 (10分30秒間) の平均速度, また, 各試行条件内のスプリント走区間の平均速度を算 出した。 最高速度は, スプリント走区間内の最高速度を 算出し, 各試行条件内の全スプリント走区間の最高速度 の平均值として評価した，直進スプリント走中の加速区 間ならびに減速区間の速度と加速度は, 最高速度に達す るまでを加速区間, 最低速度に達するまでを減速区間と した，方向転換を伴うスプリント走条件の加速区間なら びに減速区間の速度と加速度は，方向転換前と方向転換 後に分類し，それぞれ最高速度に達するまでを加速区間，
(A1)

(A2)

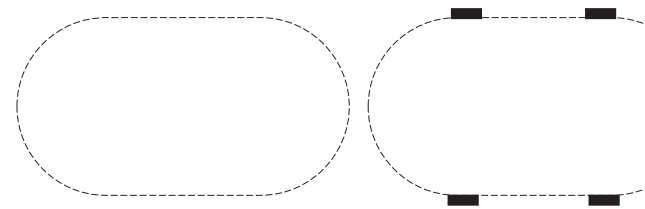

(B2)

(B3)

(B1)

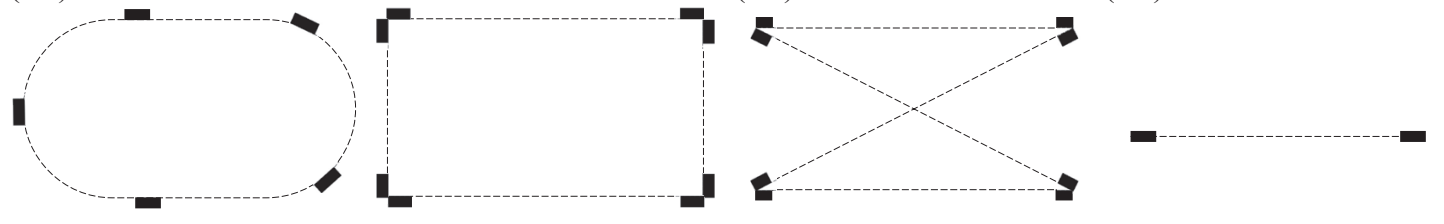

(A3)

(A3) (A4)

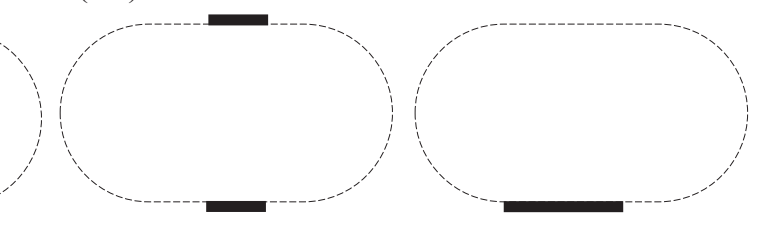

(B4)

Fig. 1 Experiment protocol

The lustrations show the procedures for experiment 1 (A1 - A4) and experiment 2 (B1 - B4), the dashed line $(\cdots)$ and straight line $(-)$ show the jogging and sprint run, respectively.

A1: Intermittent run without sprint run, A2: Intermittent run with 10 meter of straight sprint run for 12 times, A3: intermittent run with 20 meter of sprint run for 6 times, A4: Intermittent run with 40 meter of sprint run for 3 times, B1: Intermittent run with straight sprint, B2: Intermittent run with change of direction 90 angle, B3: Intermittent run with change of direction 135 angle, B4: Intermittent run with change of direction 180 angle. 
最低速度に達するまでを減速区間とした。なお，各条件 でのスプリント走に関する指標は, 条件内のスプリント 走について 1 回目と最終回のスプリント走の間で有意な 差が認められなかったため, 条件内の全てのスプリント 走の平均值として評価した.

メタボリックパワーは, di Pramperoら ${ }^{25)}$ の方法に よって, 重力加速度 $(\mathrm{g})$, 前進方向への加速度 $\left(\mathrm{a}_{\mathrm{f}}\right)$ か ら等価勾配 (ES) と等価重量（EM）を算出し，それを エネルギーコスト（EC）の式に代入し，（フットボール フィールドの場合は $\mathrm{KT}=1.29$ を乗算）それに速度（v） で乗じた值をメタボリックパワーとして採用した。

$$
\begin{aligned}
& \mathrm{ES}=\tan \left(90-\tan ^{-1} \frac{g}{a_{f}}\right) \\
& \mathrm{EM}=\left(\frac{a_{f}^{2}}{g^{2}}+1\right)
\end{aligned}
$$

$\left.\mathrm{EC}=155.4 E S^{5}-30.4 E S^{4}-43.3 E S^{3}+46.3 E S^{2}+19.5 E S+3.6\right)$ $E M \cdot K T$

$$
\text { メタボリックパワー }=\mathrm{EC} \cdot v
$$

呼気ガス分析は, 安静時から実験終了まで呼気ガスを MetaMax 3B（Cortex, ライプッィヒ, ドイッ）を用いて Breath by Breath法にて分析した。測定項目は， $\dot{\mathrm{V}} \mathrm{O}_{2}$, 二酸化炭素排出量 (carbon dioxide output: $\dot{\mathrm{V}} \mathrm{CO}_{2}$ ), $\dot{\mathrm{V}} \mathrm{E}$, 呼吸交換比 (respiratory exchange ratio: RER) であった。 MetaMax 3Bは, 先行研究によって mixing chamber 法 との比較により同程度の誤差範囲で呼気ガスを評価可能 なことが明らかにされている ${ }^{29)}$. MetaMax 3Bは, 機 器マニュアルに従って, 実験毎に規定のキャリブレー ションを実施した。 EEは呼気ガス分析装置から得られ た $\dot{\mathrm{V} O} \mathrm{O}_{2}$ と RERから Weirの式 ${ }^{30)}$ を用いて算出した。 各ス テージの呼気ガス指標は, 安静時分を差し引いた正味の 值を算出し, 回復期を含む 20 分 30 秒間のデータをステー ジあたりの数值として評価した（項目/単位/ステージ）. 主観的尺度（rating of perceived exertion: RPE）は， 400 m毎にBorg Scale ${ }^{31)}$ を用いて評価した。

統計処理 各項目の測定結果は, 平均值士標準偏差で示 した。条件間の数值の比較は, 反復測定による一元配置 分散分析を用いて有意差検定を行い, ボンフェローニの 多重比較を行なった。 また, EEを従属変数とし, 独立变 数をスプリント走の平均速度と最高速度, 1 回あたりの スプリント走距離, スプリント走回数, 方向転換角度, 加速区間と減速区間の加速度, メタボリックパワー, 方 向転換の有無, 体重としたステップワイズ法による重回
帰分析を実施した。全ての統計解析は, SPSS Statistics Version 24.0（IBM，ニューヨーク，アメリカ合衆国）を 使用した。統計学的有意水準は $5 \%$ とした。

\section{結 果}

Table 2 に実験 1 の GPSから評価された走パフォーマ ンス計測結果を示した。 スプリント走時の平均速度, 最 高速度，加速度は，SS10がSS20 とS40の間に，また SS20がSS40 との間に有意な差が認められた（p<0.01）. メタボリックパワーは, NSSとスプリント走有りの 3 条 件との間に，また，SS10とSS40，SS20とSS40の間に有 意な差が認められた（p<0.05），Table 3 には，実験 1 の 呼吸循環指標の計測結果を示した。全ての項目でスプリ ント走有りの 3 条件がNSSに比して有意に高值を示した $(\mathrm{p}<0.001)$. スプリント走有り条件内での比較において, SS10は，EEが有意に高值を示した（p<0.05）。

Table 4 に実験 2 の走パフォーマンス計測結果を示し た.スプリント走時の平均速度, 最高速度, 加速度には, 方向転換条件内にて有意な差が認められた（ $\mathrm{p}<0.05 ）$. スプリント走時の平均速度と最高速度は, CD90が CD135 と CD180の間に有意な差が認められた $(\mathrm{p}<0.01)$. スプリント走時の加速度は, CD90がCD135と CD180 の間に，CD135がCD180との間に有意な差を認めた $(\mathrm{p}<0.05)$. メタボリックパワーは方向転換条件内での有 意な差が認められなかった。 Table 5 に実験 2 の呼吸循 環指標の計測結果を示した，全ての項目で，SSと方向転 換条件に有意な差が認められた $(\mathrm{p}<0.05)$. 方向転換条 件内の比較においては，CD180のEEがCD90に比して 有意に高值を示した $(\mathrm{p}<0.05)$.

Fig. 2には，直線スプリント走条件のNSSとの差（実 験 1 ), 方向転換条件のSSとの差（実験 2 ）を示し た. SS10は， $\mathrm{VO}_{2}$ がSS40に比して有意な差が認められ $(\mathrm{p}=0.045), \mathrm{EE}$ がSS20に比して有意な差が認められた $(\mathrm{p}=0.021) . \mathrm{SS} 20$ は， $\dot{\mathrm{V} C O} \mathrm{O}_{2}$ がSS40に比して有意な差が 認められた（p=0.011）.CD180は，CD90とCD135に比 して， $\dot{\mathrm{V} O}{ }_{2}, \mathrm{EE}, \dot{\mathrm{V} C \mathrm{O}_{2}}$ が有意に大きく $(\mathrm{p}<0.05), \dot{\mathrm{V}} \mathrm{E}$ はCD90に比して有意に大きかった $(\mathrm{p}=0.042)$.

Table 6 にEE従属変数とする重回帰ステップワイ ズ分析の結果を示した。 その結果，体重，方向転換の有 無，スプリント走時の加速区間の加速度，スプリント走 平均速度, スプリント走回数, 1 回あたりのスプリント 走距離，スプリント走時の減速区間の加速度が採択され た $(\mathrm{p}<0.001)$.

\section{考察}

本研究は, サッカー競技中の $\mathrm{EE}$ を明らかにするため の基礎的研究として, 間欠的運動時の $\mathrm{EE}$ に対する加速 度の貢献を明らかにすることを目的とし, 加速度が短距 
Table 2. Running parameters assessed by Global Positioning System during intermittent straight sprint running

\begin{tabular}{|c|c|c|c|c|c|}
\hline variables & NSS & SS10 & SS20 & SS40 & $\begin{array}{l}\text { p-value* } \\
\text { (F-value) }\end{array}$ \\
\hline Average velocity $\left(\mathrm{km} \cdot \mathrm{h}^{-1}\right)$ & $6.99 \pm 0.22$ & $6.86 \pm 0.15$ & $6.96 \pm 0.22$ & $7.01 \pm 0.20$ & $\begin{array}{c}\mathrm{p}=0.098 \\
(2.560)\end{array}$ \\
\hline Maximum sprint velocity $\left(\mathrm{km} \cdot \mathrm{h}^{-1}\right)$ & & $17.96 \pm 1.22$ & $23.18 \pm 0.99^{\mathrm{bb}}$ & $27.52 \pm 0.99^{\mathrm{bb}, \mathrm{cc}}$ & $\begin{array}{l}\mathrm{p}<0.001 \\
(634.611)\end{array}$ \\
\hline Average sprint velocity $\left(\mathrm{km} \cdot \mathrm{h}^{-1}\right)$ & & $9.92 \pm 0.68$ & $13.42 \pm 0.67^{\mathrm{bb}}$ & $17.62 \pm 0.58^{\mathrm{bb}, \mathrm{cc}}$ & $\begin{array}{c}\mathrm{p}<0.001 \\
(1480.915)\end{array}$ \\
\hline Average sprint acceleration $\left(\mathrm{m} \cdot \mathrm{s}^{-2}\right)$ & & $2.47 \pm 0.37$ & $2.09 \pm 0.24^{\mathrm{bb}}$ & $1.67 \pm 0.19^{\mathrm{bb}, \mathrm{cc}}$ & $\begin{array}{c}\mathrm{p}<0.001 \\
(59.218)\end{array}$ \\
\hline Average sprint decelaration $\left(\mathrm{m} \cdot \mathrm{s}^{-2}\right)$ & & $-2.26 \pm 0.22$ & $-2.31 \pm 0.25$ & $-1.94 \pm 0.17^{\mathrm{bb}, \mathrm{cc}}$ & $\begin{array}{c}\mathrm{p}<0.001 \\
(22.593)\end{array}$ \\
\hline Metabolic power $\left(\mathrm{W} \cdot \mathrm{kg}^{-1}\right)$ & $7.71 \pm 0.39$ & $10.02 \pm 2.06^{\mathrm{aa}}$ & $9.04 \pm 0.88^{\mathrm{aa}}$ & $8.50 \pm 0.52^{\mathrm{aa}, \mathrm{b}, \mathrm{c}}$ & $\begin{array}{l}\mathrm{p}=0.001 \\
(13.156)\end{array}$ \\
\hline
\end{tabular}

Date are shown as mean with standard deviation

NSS: Intermittent run without sprint run, SS10: Intermittent run with 10 meter of straight sprint run for 12 times, SS20: Intermittent run with 20 meter of sprint run for 6 times, SS40: Intermittent run with 40 meter of sprint run for 3 times.

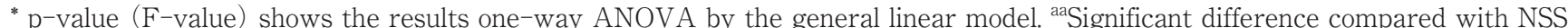

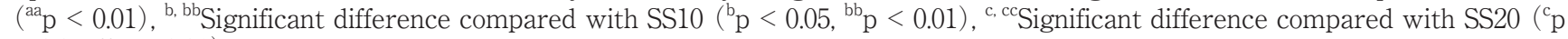
$\left.<0.05,{ }^{\mathrm{cc}} \mathrm{p}<0.01\right)$.

Table 3. Physiological response during intermittent straight sprint running.

\begin{tabular}{|c|c|c|c|c|c|}
\hline variables & NSS & SS10 & SS20 & SS40 & $\begin{array}{l}\text { p-value* } \\
\text { (F-value) }\end{array}$ \\
\hline$\dot{\mathrm{VO}}_{2}\left(\mathrm{~L} \cdot \min ^{-1}\right)$ & $0.69 \pm 0.11$ & $0.91 \pm 0.12^{\text {aa }}$ & $0.88 \pm 0.13^{\text {aa }}$ & $0.88 \pm 0.12^{\mathrm{aa}}$ & $\begin{array}{l}\mathrm{p}<0.001 \\
(119.416)\end{array}$ \\
\hline$\dot{\mathrm{VCO}}_{2}\left(\mathrm{~L} \cdot \mathrm{min}^{-1}\right)$ & $0.62 \pm 0.11$ & $0.79 \pm 0.14^{\text {aa }}$ & $0.78 \pm 0.12^{\mathrm{aa}}$ & $0.83 \pm 0.13^{\mathrm{aa}, \mathrm{c}}$ & $\begin{array}{c}\mathrm{p}<0.001 \\
(81.823)\end{array}$ \\
\hline$\dot{\mathrm{VE}}\left(\mathrm{L} \cdot \mathrm{min}^{-1}\right)$ & $17.9 \pm 3.4$ & $23.6 \pm 4.1^{\text {aa }}$ & $23.8 \pm 4.3^{\text {aa }}$ & $24.9 \pm 3.8^{\mathrm{aa}}$ & $\begin{array}{c}\mathrm{p}<0.001 \\
(78.566)\end{array}$ \\
\hline $\mathrm{EE}\left(\mathrm{kcal} \cdot\right.$ stage $\left.^{-1}\right)$ & $68.83 \pm 11.0$ & $90.80 \pm 12.9^{\text {aа }}$ & $87.74 \pm 12.5^{\text {aa, } b}$ & $88.24 \pm 12.1^{\text {aa }}$ & $\begin{array}{l}\mathrm{p}<0.001 \\
(134.766)\end{array}$ \\
\hline HR $\left(\right.$ beat $\left.\cdot \min ^{-1}\right)$ & $105 \pm 14$ & $123 \pm 17^{\text {aa }}$ & $123 \pm 16^{\mathrm{aa}}$ & $121 \pm 14^{\text {aa }}$ & $\begin{array}{l}\mathrm{p}<0.001 \\
(42.442)\end{array}$ \\
\hline RPE & $9 \pm 2$ & $12 \pm 2^{\mathrm{aa}}$ & $12 \pm 1^{\text {aa }}$ & $13 \pm 2^{\text {aa }}$ & $\begin{array}{c}\mathrm{p}<0.001 \\
(24.510)\end{array}$ \\
\hline
\end{tabular}

Date are shown as mean with standard deviation.

NSS: Intermittent run without sprint run, SS10: Intermittent run with 10 meter of straight sprint run for 12 times, SS20: Intermittent run with 20 meter of sprint run for 6 times, SS40: Intermittent run with 40 meter of sprint run for 3 times.

$\dot{\mathrm{VO}_{2}}$ : Oxygen uptake, $\dot{\mathrm{V} C O}{ }_{2}$ : Carbon dioxide output, $\dot{\mathrm{VE}}$ : Ventilation, EE: Energy expenditure, HR: Heart rate, RPE: Rating of perceived exertion.

${ }^{*} \mathrm{p}^{-}$value $\left(\mathrm{F}\right.$-value) shows the results one-way ANOVA by the general linear model. ${ }^{\text {aa }}$ Significant difference compared with NSS $\left({ }^{a a} \mathrm{p}<0.01\right)$, ${ }^{\mathrm{b}}$ Significant difference compared with SS10 ( $\left.{ }^{\mathrm{b}} \mathrm{p}<0.05\right)$, ' Significant difference compared with SS20 ( $\left.{ }^{\mathrm{c}} \mathrm{p}<0.05\right)$.

離スプリント走を含む間欠的運動中の $\mathrm{EE} の$ 説明要因で あるとの仮説を検証した，その結果， $\mathrm{EE}$ は，スプリント 走無し条件に比してスプリント走有り条件で増加し，さ らに，直線スプリント走に比して方向転換を含むスプリ
ント走条件にて更なる増加を認めた。加速度は, $\mathrm{EE}$ と 同様に, 直線スプリント走, 方向転換を含むスプリント 走の順に大きくなった。 さらに，重回帰分析の結果にお いても, 加速度と方向転換の有無が $\mathrm{EE} の$ 説明因子とし 
Table 4. Running parameters assessed by Global Positioning System during intermittent sprint running with change of direction.

\begin{tabular}{|c|c|c|c|c|c|}
\hline variables & SS & CD90 & CD135 & CD180 & $\begin{array}{l}\text { p-value* } \\
\text { (F-value) }\end{array}$ \\
\hline Average velocity $\left(\mathrm{km} \cdot \mathrm{h}^{-1}\right)$ & $6.86 \pm 0.21$ & $7.11 \pm 0.11^{\mathrm{a}}$ & $7.08 \pm 0.15$ & $7.04 \pm 0.17$ & $\begin{array}{c}\mathrm{P}=0.001 \\
(6.813)\end{array}$ \\
\hline Maximum sprint velocity $\left(\mathrm{km} \cdot \mathrm{h}^{-1}\right)$ & $18.51 \pm 1.09$ & $13.79 \pm 0.74^{\text {aa }}$ & $12.87 \pm 0.69^{\mathrm{aa}, \mathrm{bb}}$ & $13.13 \pm 0.55^{\mathrm{aa}, \mathrm{bb}}$ & $\begin{array}{l}\mathrm{P}<0.001 \\
(395.701)\end{array}$ \\
\hline Average sprint velocity $\left(\mathrm{km} \cdot \mathrm{h}^{-1}\right)$ & $10.32 \pm 0.64$ & $8.69 \pm 0.53^{\text {aa }}$ & $7.88 \pm 0.59^{\text {aa, bb }}$ & $7.78 \pm 0.48^{\mathrm{aa}, \mathrm{bb}}$ & $\begin{array}{l}\mathrm{P}<0.001 \\
(114.032)\end{array}$ \\
\hline Average sprint acceleration $\left(\mathrm{m} \cdot \mathrm{s}^{-2}\right)$ & $2.80 \pm 0.49$ & $2.30 \pm 0.32^{\mathrm{aa}}$ & $2.57 \pm 0.41^{b}$ & $2.94 \pm 0.41^{\mathrm{bb}, \mathrm{cc}}$ & $\begin{array}{l}\mathrm{P}<0.001 \\
(28.214)\end{array}$ \\
\hline Average sprint decelaration $\left(\mathrm{m} \cdot \mathrm{s}^{-2}\right)$ & $-2.49 \pm 0.22$ & $-1.88 \pm 0.15^{\text {aa }}$ & $-2.42 \pm 0.24^{\mathrm{bb}}$ & $-3.01 \pm 0.22^{a a, b b, c c}$ & $\begin{array}{l}\mathrm{P}<0.001 \\
(103.411)\end{array}$ \\
\hline Metabolic power $\left(\mathrm{W} \cdot \mathrm{kg}^{-1}\right)$ & $11.21 \pm 3.79$ & $13.00 \pm 3.38$ & $13.81 \pm 4.00^{\mathrm{aa}}$ & $13.15 \pm 3.34^{\mathrm{a}}$ & $\begin{array}{c}\mathrm{P}=0.001 \\
(7.084)\end{array}$ \\
\hline
\end{tabular}

Date are shown as mean with standard deviation.

SS: Intermittent run with straight sprint. CD90: Intermittent run with change of direction 90 angle. CD135: Intermittent run with change of direction 135 angle. CD180: Intermittent run with change of direction 180 angle.

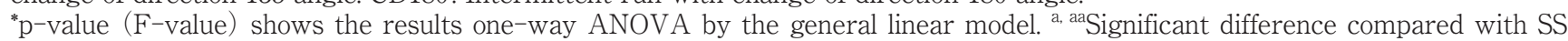
$\left({ }^{\mathrm{a}} \mathrm{p}<0.05,{ }^{\text {aa }} \mathrm{p}<0.01\right)$, ${ }^{\mathrm{b}}$ bb Significant difference compared with CD90 ( $\left.{ }^{\mathrm{b}} \mathrm{p}<0.05,{ }^{\mathrm{bb}} \mathrm{p}<0.01\right)$, ${ }^{\mathrm{cc}}$ Significant difference compared with CD135 ( $\left.{ }^{\mathrm{cc}} \mathrm{p}<0.01\right)$.

Table 5. Physiological response during intermittent sprint running with change of direction.

\begin{tabular}{|c|c|c|c|c|c|}
\hline variables & SS & CD90 & CD135 & CD180 & $\begin{array}{l}\text { p-value* } \\
\text { (F-value) }\end{array}$ \\
\hline$\dot{\mathrm{VO}}_{2}\left(\mathrm{~L} \cdot \mathrm{min}^{-1}\right)$ & $0.95 \pm 0.17$ & $1.01 \pm 0.18$ & $1.00 \pm 0.17$ & $1.05 \pm 0.19^{\text {aa, bb, c }}$ & $\begin{array}{l}\mathrm{P}<0.001 \\
(12.115)\end{array}$ \\
\hline$\dot{\mathrm{V} C O}_{2}\left(\mathrm{~L} \cdot \min ^{-1}\right)$ & $0.88 \pm 0.15$ & $0.94 \pm 0.16$ & $0.93 \pm 0.15$ & $0.98 \pm 0.17^{\text {aa, b }}$ & $\begin{array}{l}\mathrm{P}<0.001 \\
(11.367)\end{array}$ \\
\hline$\dot{\mathrm{VE}} \quad\left(\mathrm{L} \cdot \mathrm{min}^{-1}\right)$ & $22.7 \pm 4.9$ & $25.8 \pm 5.8^{\mathrm{aa}}$ & $26.4 \pm 5.7^{\text {aa }}$ & $26.7 \pm 6.0^{\mathrm{aa}}$ & $\begin{array}{l}\mathrm{P}<0.001 \\
(22.475)\end{array}$ \\
\hline $\mathrm{EE}\left(\mathrm{kcal} \cdot \mathrm{stage}^{-1}\right)$ & $95.51 \pm 16.6$ & $101.18 \pm 17.3^{\mathrm{a}}$ & $99.88 \pm 16.1$ & $104.95 \pm 18.0^{\mathrm{aa}, \mathrm{b}}$ & $\begin{array}{r}\mathrm{P}<0.001 \\
(10.378)\end{array}$ \\
\hline HR $\left(\right.$ beat $\left.\cdot \min ^{-1}\right)$ & $113 \pm 10$ & $122 \pm 12^{\text {aa }}$ & $122 \pm 10^{\text {aa }}$ & $124 \pm 11^{\text {aa }}$ & $\begin{array}{c}\mathrm{P}<0.001 \\
(28.508)\end{array}$ \\
\hline RPE & $11 \pm 2$ & $13 \pm 1$ & $12 \pm 2$ & $12 \pm 2^{\text {aa }}$ & $\begin{array}{c}\mathrm{P}=0.032 \\
(4.929)\end{array}$ \\
\hline
\end{tabular}

Date are shown as mean with standard deviation.

SS: Intermittent run with straight sprint. CD90: Intermittent run with change of direction 90 angle. CD135: Intermittent run with change of direction 135 angle. CD180: Intermittent run with change of direction 180 angle.

$\dot{\mathrm{V}} \mathrm{O}_{2}$ : Oxygen uptake, $\dot{\mathrm{V}} \mathrm{CO}_{2}$ : Carbon dioxide output, $\dot{\mathrm{V} E}$ : Ventilation, EE: Energy expenditure, HR: Heart rate, RPE: Rating of perceived exertion.

" $\mathrm{p}^{-}$value $(\mathrm{F}$-value $)$ shows the results one-way ANOVA by the general linear model. ${ }^{\text {a, aa }}$ Significant difference compared with SS $\left({ }^{\mathrm{a}} \mathrm{p}<0.05,{ }^{\text {aa }} \mathrm{p}<0.01\right)$, ${ }^{\mathrm{b}}$ bb Significant difference compared with CD90 $\left({ }^{\mathrm{b}} \mathrm{p}<0.05,{ }^{\mathrm{bb}} \mathrm{p}<0.01\right)$, 'Significant difference compared with CD135 ( $\left.{ }^{\mathrm{c}} \mathrm{p}<0.05\right)$.

て採択された。これらの結果は, 本研究のオリジナルの 知見であり, 総移動距離を統一した距離と方向転換角度 の異なるスプリント走条件での間欠運動時において，ス
プリント走行時の加速度が $\mathrm{EE} に$ 貢献することを示唆す る。すなわち, 位置情報の連続的かつ高頻度の分析に基 づく瞬時の加速度・減速度は, スプリント走時の EEの 
(a)

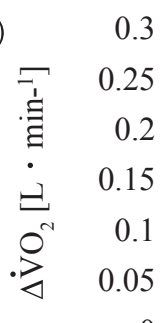

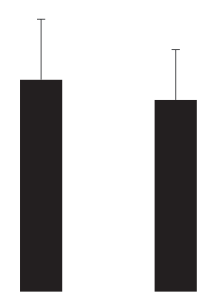

(b)

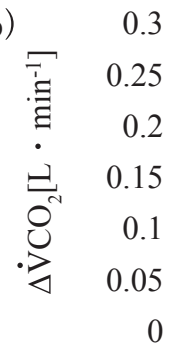

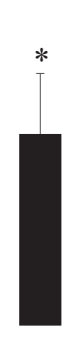

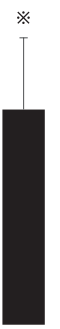

(c)

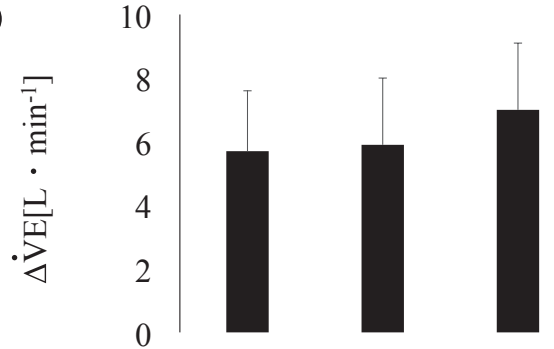

(d)

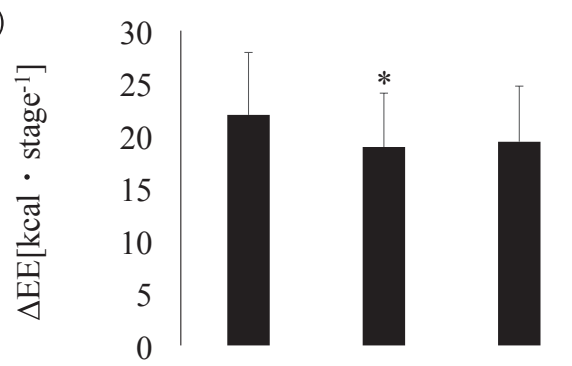

(e)

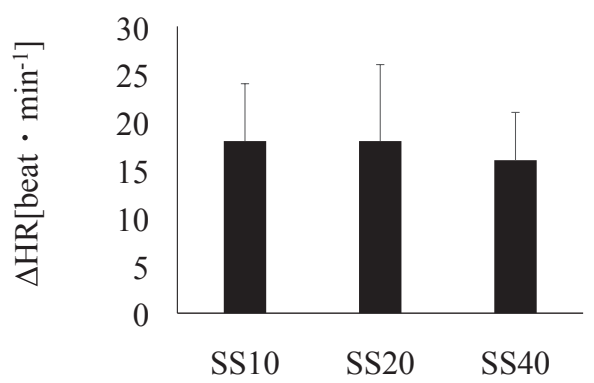

(a)

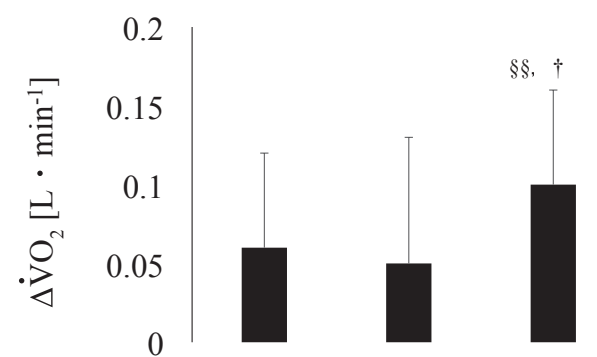

(b)

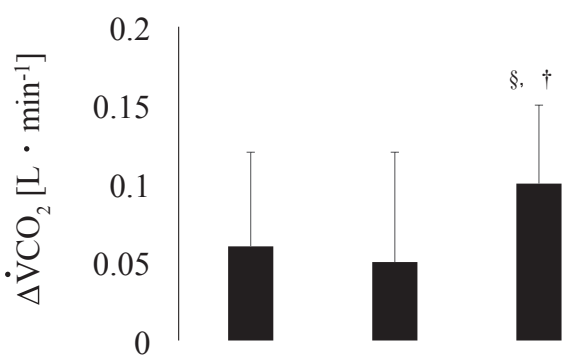

(c)

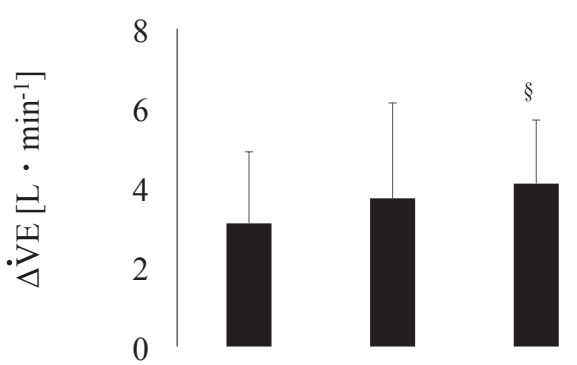

(d)

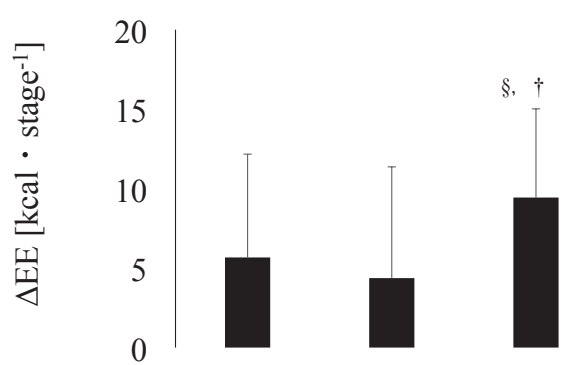

(e)

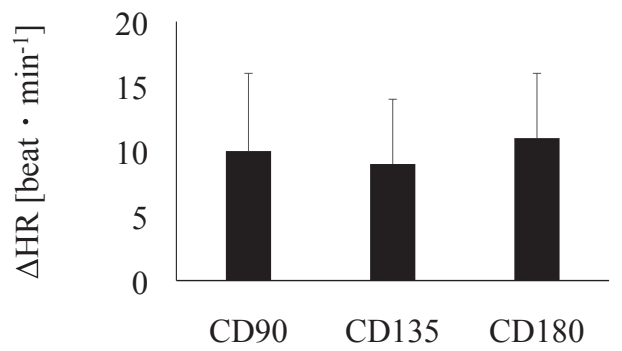

Fig. 2 Additional physiological response by sprint run (left) and change of direction (right).

The left illustrations show the results of experimental 1. The right illustrations show the results of experimental 2.

$\dot{\mathrm{V}}_{2}$ : Oxygen uptake, $\dot{\mathrm{VCO}}_{2}$ : Carbon dioxide output, $\dot{\mathrm{V} E}$ : Ventilation, EE: Energy expenditure, HR: Heart rate, SS10: Intermittent run with 10 meter of straight sprint run for 12 times, SS20: Intermittent run with 20 meter of sprint run for 6 times, SS40: Intermittent run with 40 meter of sprint run for 3 times, CD90: Intermittent run with change of direction 90 angle. CD135: Intermittent run with change of direction 135 angle. CD180: Intermittent run with change of direction 180 angle. *Significant difference compared with SS10 ( $\left.{ }^{*} \mathrm{p}<0.05\right)$, *Significant difference compared with SS20 (*p < 0.05). \$. \$§Significant difference compared with CD90 $\left({ }^{\S} \mathrm{p}<0.05,{ }^{\S} \mathrm{p}<0.01\right)$. "Significant difference compared with CD135 $\left({ }^{\dagger} \mathrm{p}<0.05\right)$.

推定精度の向上を介して, サッカーのEEの推定精度向 上に寄与すると考えられた.

本研究は，スプリント走を含めた間欠的運動中の HR や RPE，EEなどの身体負担がスプリント走を含まない
条件に比して高值を示すことを確認した。本研究の実験

で用いた 8 条件は全て移動距離が $1,200 \mathrm{~m}$ に統一され, 間欠的運動全体の移動速度の変動が $3.6 \%(114 \mathrm{~m} /$ 分 $-119 \mathrm{~m} /$ 分）であったにも関わらず，EEがスプリント 
Table 6. Contribution of running parameters by global positioning system to directly measured energy expenditure.

\begin{tabular}{|c|c|c|c|}
\hline Dependent variable & & Independent variable (Standard slope) & $r^{2}(p-v a l u e)$ \\
\hline \multirow[t]{12}{*}{ Energy expenditure } & Step 1 & Body Weight $(0.712)$ & $0.500(\mathrm{p}<0.001)$ \\
\hline & Step 2 & Body Weight $(0.749)+$ Prevalence of direction change $(0.475)$ & $0.724(\mathrm{p}<0.001)$ \\
\hline & Step 3 & Body Weight $(0.761)+$ Prevalence of direction change $(0.370)+$ Average acceleration during sprint run $(0.205)$ & $0.752(\mathrm{p}<0.001)$ \\
\hline & Step 4 & Body Weight $(0.775)+$ Prevalence of direction change $(0.498)+$ Average acceleration during sprint run $(0.311)+$ & $0.768(\mathrm{p}<0.001)$ \\
\hline & & Average velocity during sprint run $(0.244)$ & \\
\hline & Step 5 & Body Weight $(0.800)+$ Prevalence of direction change $(0.308)+$ Average acceleration during sprint run $(0.264)+$ & $0.802(\mathrm{p}<0.001)$ \\
\hline & & Average velocity during sprint run $(0.983)+$ Number of sprint run $(0.941)$ & \\
\hline & Step 6 & Body Weight $(0.817)+$ Prevalence of direction change $(0.514)+$ Average acceleration during sprint run $(0.236)+$ & $0.816(\mathrm{p}<0.001)$ \\
\hline & & Average velocity during sprint run $(1.493)+$ Number of sprint run $(0.772)+$ Distance during sprint run $(-0.570)$ & \\
\hline & Step 7 & Body Weight $(0.825)+$ Prevalence of direction change $(0.477)+$ Average acceleration during sprint run $(0.155)+$ & $0.826(\mathrm{p}<0.001)$ \\
\hline & & Average velocity during sprint run $(1.658)+$ Number of sprint run $(0.960)+$ Distance during sprint run $(-0.575)+$ & \\
\hline & & Average deceleration during sprint run $(-0.140)$ & \\
\hline
\end{tabular}

Independent variables: Angle of direction Change, Average acceleration during sprint run, Average deceleration during sprint run, Average velocity during sprint run, Body weight, Distance during sprint run, Maximal velocity during sprint run, Metabolic power, Number of sprint run, Prevalence of direction change.

走により 18.91-36.12 kcal（27-41\%）増加した，同様に Cipryan ら ${ }^{14)} も ，$ 運動時間を統一した連続的運動中と間 欠的運動中の身体負担を比較し, 連続的運動時に比して 間欠的運動時に HR や $\dot{\mathrm{V} O} \mathrm{O}_{2}$ ，RPEが46\%（20-101\%）高 值であることを報告している。また, Kelly ら ${ }^{32)}$ も運動 時間を統一した連続的運動中と間欠的運動中の身体負担 を比較し, 連続的運動時に比して間欠的運動時にEEが 49\%高值であることを報告した，本研究の結果もこれら の先行研究に一致しており, スプリント走の付加による $\mathrm{EE}$ の増大, また, 同一距離のスプリント走を分割する ことによりさらなる $\mathrm{EE} の$ 増大, さらに, 重回帰分析の 結果も加速度が $\mathrm{EE}$ の説明変数として貢献している事を 確認した，我々の知る限りフィールド実験にて加速度と $\mathrm{EE}$ の両者を実測し, 間欠的運動中の $\mathrm{EE}$ に対する加速度 の貢献を示した結果は本研究が始めてである.

また，本研究は，方向転換を伴うスプリントが間欠的 運動中のEEをさらに増大させる事を確認した。本研究 の実験 2 に扔いては, 方向転換スプリント走により $\mathrm{EE}$ の4.37-9.44 kcal (4.6-9.9\%) の増加を認めた. Oxendale ら ${ }^{33)}$ は, 本研究と同様に, 同距離のジョギングやスプ リント走のみでの直進運動パターンに比して, 方向転換 を含めたジョギングとスプリント走での運動パターンの $\mathrm{EE}$ が $6.8 \%$ 増大したと報告した，さらに，本研究におい ては, EEの直接測定と同時に高精度の位置情報分析に より，方向転換を付加することによる $\mathrm{EE} の$ 増大の原因
が方向転換に伴う加速度の増大であることを示す結果を 得た。すなわち，方向転換を伴うスプリント走を含む間 欠的運動時には, $\mathrm{EE}$ と加速度の増大が認められ，重回 帰分析の結果も方向転換の有無と加速度が $\mathrm{EE}$ の説明要 因として採択された。これらの結果は, 間欠的運動中に 扔いて，スプリント走や方向転換に伴う加速度の増加が $\mathrm{EE} の$ 増大に貢献していることを示し, 位置情報から得 られる加速度がサッカーの試合中の EEの推定指標とし て有用となる可能性を示唆している.

本研究の結果は, 加速度が $\mathrm{EE}$ の推定精度の向上に貢 献することを示したが，位置情報からのサッカーの競技 中の EEを推定するためには未だに多くの課題が山積し ている、サッカーの競技は, 単純な移動として評価でき ない身体負荷であるジャンプ動作やスライディング動作 などがある、サッカーに拈いては，1試合のうちボール を伴う動作がわずか 1 分程度であるが，それに伴う付加 EEも無視できない. Pirasらは年，ドリブル動作が同一 速度での走行に比して付加 $\mathrm{EE}$ を $9.6 \%$ 程度増大させるこ とを報告している，そのほか，ジャンプやバック走など のサッカーの特異的な動作は, 身体負担を増大すること が明らかになっているが35)，これらの動作を位置情報の みでは判別することができない，従って，無拘束条件で のサッカーの試合中の EEの定量のためには, 映像分析 やセンサー技術と連動したサッカーの特異的動作の動作 判別アルゴリズムの開発も求められる. 
本研究は, 加速局面のスプリント走における加速度が EEに果たす貢献度を示している。すなわち, 本研究に おける最高速度の低さは, 研究開始前の想定を超えて低 值であった。本研究は, これまでのサッカーの試合の分 析結果に基づいて 10-40 m を直線スプリント走区間とし て設定し（実験 1 ），さらに大きな加速度を得るとの期 待から単回あたりの移動距離を $10 \mathrm{~m}$ とした（実験 2 ）. その結果, 研究開始前に想定した通りに加速度がスプリ ント走距離に反比例し, 方向転換角度に比例したが, 全 カスプリント走時の最高速度が実験 1 が $18 \mathrm{~km} / \mathrm{h}$ 程度で 実験 2 が $13 \mathrm{~km} / \mathrm{h}$ 程度であり, 日常的にサッカーを行う 大学生であったことを踏まえると, 最高速度に達してい たとは考え難い結果となった。特に, 実験 2 においては, $10 \mathrm{~m}$ のスプリント走区間の中間地点で方向転換を行った ため，実質的に $5 \mathrm{~m}$ のスプリント走後に減速してその後 に再加速する運動になり，スプリント走中の最高速度も 実験 1 に比べて低值となった。ささらに, 実験 2 を天然芝 で実験を実施したことも最高速度の低下に寄与したと推 測される。頻回の短距離スプリント走や方向転換角度の 大きなスプリント走が加速度の増大を介して $\mathrm{EE} に$ 貢献 することは移動距離とは独立しており，この点において はスプリント走距離を延長しても同様と推測されるが, 本研究で得られた最高速度の低さを考慮すれば, 最高速 度に到達するような距離での走行での条件下における加 速度が $\mathrm{EE} に$ 果たす貢献度を確認する必要がある。本研 究は, サッカーの試合を想定してスプリント走の距離を 10-40 mに設定しており，加速区間の後の最高速度維持 区間を含む移動距離での条件下では加速度に由来する工 ネルギー需要が相対的に少なくなることも想定される.

本研究には, いくつかの限界がある. 第一に, 本研究は, 同一距離での間欠的走行運動において $\mathrm{EE} に$ 対するスプ リント走時の加速度の貢献を示した。すなわち, これま での生理学的知見に基づけば，単位時間あたりの EEが 距離（速度）に依存することが明白であり, サッカーの 試合全体の $\mathrm{EE}$ は, 加速度よりも移動距離に依存するこ とは明らかであろう。それ故, 加速度の重回帰分析の寄 与率も高くなかったが, 本研究の結果は, 単位時間あた りの距離や平均速度よりも，単位時間あたりのスプリン 卜走時の加速度が継時的な身体負担の評価として有用で あり，間接的にサッカーの試合全体の移動距離の予測や EEの推定に応用できると考えている。また，本研究の 対象者はサッカー経験のある男子大学生であり, エリー トサッカー選手やレクリエーションサッカー愛好家で同 様の結果が得られるかは不明である。従って, 最大疾走 速度の個人差を含んだ対象者の特性に伴う加速度の变化 が結果に影響を与えない可能性を否定できない. 最後に,

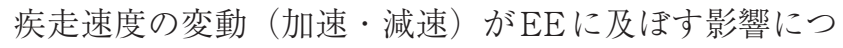
いては今後の課題であり, 呼吸循環応答や骨格筋での代
謝基質の変動を含めた研究成果が期待される.

\section{結語}

本研究は, サッカーの競技中の $\mathrm{EE}$ を明らかにするた めの基礎的研究として, 総移動距離が同一の条件下にて, 全力スプリント走の回数と方向転換角度の増減に基づく 加速度の増減が $\mathrm{EE} に$ 対する貢献を検討した。 その結果, 間欠的運動にスプリント走を加えることで $\mathrm{EE} は$ は増加し,

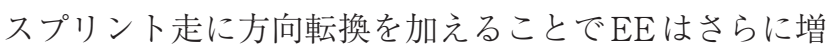
加することを確認した。 その要因として, 加速度が体重 や方向転換の有無に加えて $\mathrm{EE} に$ 貢献していることを示 唆する結果を得た。これらの結果は, 総移動距離を統一 した距離と方向転換角度の異なるスプリント走条件での 間欠的運動時において，スプリント走行時の加速度が EEに貢献することを示唆する。すなわち，位置情報の 連続的かつ高頻度の分析は, サッカーの $\mathrm{EE} の$ 定量の精 度改善に有効であると考えられた。無拘束条件でのサッ カーの試合中の EEの定量のためには，映像分析やセン サー技術と連動したサッカーの特異的動作の動作判別ア ルゴリズムの開発が必要である.

利益相反自己申告 : 申告すべきものはなし

\section{謝 辞}

本研究の一部は, 岡山県立特別研究費ならびにウエスコ 学術振興財団の支援を受けて実施された。

\section{引用文献}

1) FIFA. FIFA magazine 2007, http://www.fifa.com/ $\mathrm{mm}$ /document/fifafacts/bcoffsurv/emaga_9384_10704. pdf（閲覧日2017年10月11日）.

2) Krustrup P, Nielsen JJ, Krustrup BR, Christensen JF, Pedersen H, Randers MB, Aagaard P, Petersen AM, Nybo L, Bangsbo J. Recreational soccer is an effective health-promoting activity for untrained men. $\mathrm{Br} J$ Sports Med 43: 825-831, 2009.

3) Krustrup P, Helge EW, Hansen PR, Aagaard P, Hagman M, Randers MB, de Sousa M, Mohr M. Effects of recreational football on women's fitness and health: adaptations and mechanisms. Eur J Appl Physiol 118: 11-32, 2018.

4) Science and soccer developing elite performers. Third Edition. (Williams AM), Routledge, London, England, 2013.

5) Sarmento H, Clemente FM, Araújo D, Davids K, McRobert A, Figueiredo A. What performance analysts need to know about research trends in association football (2012-2016): A systematic review. Sports Med 48: 799-836, 2017.

6) Sarmento H, Anguera MT, Pereira A, Araújo D. Talent identification and development in male football: a 
systematic review. Sports Med 48: 907-931, 2018.

7) Carling C. Analysis of physical activity profiles when running with the ball in a professional soccer team. $J$ Sports Sci 28: 319-326, 2010.

8) Chmura P, Andrzejewski M, Konefał M, Mroczek D, Rokita A, Chmura J. Analysis of motor activities of professional soccer players during the 2014 world cup in Brazil. J Hum Kinet 56: 187-195, 2017.

9) Osgnach C, Poser S, Bernardini R, Rinaldo R, di Prampero PE. Energy cost and metabolic power in elite soccer: A new match analysis approach. Med Sci Sports Exerc 42: 170-178, 2010.

10) Bradley PS, Sheldon W, Wooster B, Olsen P, Boanas P, Krustrup P. High-intensity running in English FA Premier League soccer matches. J Sports Sci 27: 159168, 2009.

11) Ainsworth BE, Haskell WL, Whitt MC, Irwin ML, Swartz AM, Strath SJ, O'Brien WL, Bassett DR Jr, Schmitz KH, Emplaincourt PO, Jacobs DR Jr, Leon AS. Compendium of physical activities: an update of activity codes and MET intensities. Med Sci Sports Exerc 32: 498-504, 2000.

12) Krustrup P, Mohr M, Ellingsgaard H, Bangsbo J. Physical demands during an elite female soccer game: importance of training status. Med Sci Sports Exerc 37: 1242-1248, 2005.

13) Bangsbo J, Hansen PR, Dvorak J, Krustrup P. Recreational football for disease prevention and treatment in untrained men: a narrative review examining cardiovascular health, lipid profile, body composition, muscle strength and functional capacity. Br J Sports Med 49: 568-576, 2015.

14) Cipryan L, Tschakert G, Hofmann P. Acute and postexercise physiological responses to high-intensity interval training in endurance and sprint athletes. $J$ Sports Sci Med 16: 219-229, 2017.

15) Reilly T, Bangsbo J, Franks A. Anthropometric and physiological predispositions for elite soccer. J Sports Sci 18: 669-683, 2000.

16) Hoppe MW, Baumgart C, Slomka M, Polglaze T, Freiwald J. Variability of metabolic power date in elite soccer players during pre-season matches. J Hum Kinet 58: 233-245, 2017.

17）大橋二郎, 鈴木 滋, 大串哲郎, 河合一武：サッカー選手 の試合中における移動スピードの変化と分布, サッカー 医科学研究会報告書, 7:36-39, 1987.

18）塩川満久, 沖原謙, 菅輝, 野地照樹：サッカーにおける 新しいゲーム分析の試み - 3D 画像分析による再現一, サッカー医科学研究報告書, 17: 165-170, 1997.

19) J.LEAGUE. 成績・データ, https://www.jleague.jp/ stats/2017/(閲覧日2018年 2 月 7 日).

20) Bloomfield J, Polman R, O'Donoghue P. Physical demands of different positions in FA Premier League soccer. J Sports Sci Med 6: 63-70, 2007.

21) Ebine N, Rafamantanantsoa HH, Nayuki Y, Yamanaka K, Tashima K, Ono T, Saitoh S, Jones PJ. Measurement of total energy expenditure by the doubly labelled water method in professional soccer players. $J$ Sports Sci 20: 391-397, 2002.

22）秋田信也, 菊池武道, 鍋島和夫：サロンフットボールの エネルギー消費量とボールコンタクトについて, サッ カー医科学研究会報告書, 4: 137-141, 1984.

23）杉山允宏, 岡田栄治：スポーツ活動・身体運動の運動強 度, 愛媛大学教育学部紀要, 40: 65-76, 1994.

24) Beato M, Impellizzeri FM, Coratella G, Schena F. Quantification of energy expenditure of recreational football. J Sports Sci 34: 2185-2188, 2016.

25) di Prampero PE, Fusi S, Sepulcri L, Morin JB, Belli A, Antonutto G. Sprint running: a new energetic approach. J Exp Biol 208: 2809-2816, 2005.

26）日本サッカー協会. Laws of the Game, 日本サッカー協 会, 東京都, 32, 2017.

27) Lago C. The influence of match location, quality of opposition, and match status on possession strategies in professional association football. J Sports Sci 27: 14631469, 2009.

28) Köklü Y, Aralan Y, Alemdaroğlu U, Duffield R. Accuracy and reliability of SPI Pro X global positioning system devices for measuring movement demands of team sports. J Sports Med Phys Fitness 55: 471-477, 2015.

29) Meyer T, Georg T, Becker C, Kindermann W. Reliability of gas exchange measurements from two different spiroergometry systems. Int J Sports Med 22: 593597, 2001.

30) Weir JB. New methods for calculating metabolic rate with special reference to protein metabolism. J Physiol 109: 1-9, 1949.

31) Borg G. Perceived exertion as an indicator of somatic stress. Scand J Rehabil Med 2: 92-98, 1970.

32) Kelly B, King JA, Goerlach J, Nimmo MA. The impact of high-intensity intermittent exercise on resting metabolic rate in healthy males. Eur J Appl Physiol 113: 3039-3047, 2013.

33) Oxendale CL, Highton J, Twist C. Energy expenditure, metabolic power and high speed activity during linear and multi-directional running. J Sci Med Sport 20: 957-961, 2017.

34) Piras A, Raffi M, Atmatzidis C, Merni F, Di Michele R. The energy cost of running with the ball in soccer. Int J Sports Med 38: 877-882, 2017.

35) Zagato AM, Papoti M, Da Silva ASR, Barbieri RA, Campos EZ, Ferreira EC, Loures JP, Chamari K. The hoff circuit test is more specific than an incremental treadmill test to assess endurance with the ball in youth soccer players. Biol Sport 33: 263-268, 2016. 